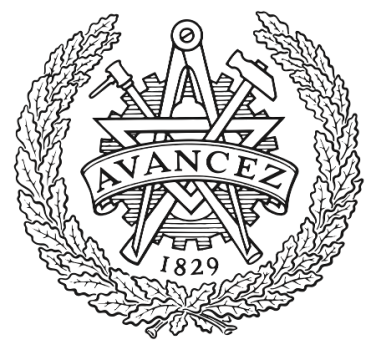

CHALMERS

UNIVERSITY OF TECHNOLOGY

\title{
Leadership under construction: A qualitative exploration of leadership processes in construction companies in Sweden.
}

Downloaded from: https://research.chalmers.se, 2023-04-26 14:29 UTC

Citation for the original published paper (version of record):

Löwstedt, M., Fasth, J., Styhre, A. (2021). Leadership under construction: A qualitative exploration of leadership processes in

construction companies in Sweden.. Journal of Construction Engineering and Management - ASCE, 147(12). http://dx.doi.org/10.1061/(ASCE)CO.1943-7862.0002205

N.B. When citing this work, cite the original published paper. 


\section{To cite this paper:}

2 Löwstedt. M, ; Fasth. J \& Styhre. A (2021) Leadership under construction: A qualitative

3 exploration of leadership processes in construction companies in Sweden. Journal of

4 Construction Engineering and Management. 147(12)

5

DOI: 1 https://ascelibrary.org/doi/10.1061/\%28ASCE\%29CO.1943-7862.0002205

Link to ASCE library:

https://ascelibrary.org/action/doSearch?AllField=leadership+under+construction

11 Leadership under construction: A qualitative exploration of

leadership processes in construction companies in Sweden

*Associate Professor, Department of Technology Management, Chalmers University of

17 Technology, Gothenburg, 41296 Sweden.

e-mail: martin.lowstedt@,chalmers.se, Phone: +46731542398

^ Senior Lecturer, Department of Business Administration, University of Gothenburg,

21 Gothenburg, 41124 Sweden.

${ }^{\wedge}$ Professor, Department of Business Administration, University of Gothenburg,

24 Gothenburg, 41124 Sweden.

\section{Abstract}


Leadership has increasingly been advocated as a potent organizing practice, linked positively to several performance dimensions as well as successful organizational development and change. Despite these alleged promises, the specific characteristics of leadership processes as they unfold in a construction context have not been fully captured by construction researchers. This paper is predicated on an identified lack of methodological richness underlying leadership studies in construction. While a growing number of contributions have quantitatively tested the ideas and models of leadership scholars, few have qualitatively explored the experiences and interpretations of the actual people that practice leadership in their daily work in construction companies. Drawing on a rich qualitative interview study, this paper analyzes open-ended stories about leadership in the largest construction companies in Sweden. The findings show how leadership styles have been shaped to align with traditional work and organizing principles, but also how they, by the same token, pose a seemingly unresolved tension with change initiatives that seek to reorganize to improve organizational performance. Altogether these findings indicate that there are grounds to question the transformative potential of leadership in construction companies, as practiced today. The paper concludes by outlining the practical implications of these findings, together with some analytical generalizations that can serve as pointers for a strengthened leadership agenda in construction research, one that is characterized by an increased methodological richness and accentuated focus on the context-specific aspects of leadership.

Keywords: construction companies, leadership; managerial work; qualitative method; social process

INTRODUCTION

There is no mistaking that leadership is a hot topic today, frequently portrayed as a core principle for every modern organization and industry aspiring for eminence and success. This popularized discourse is grounded on a myriad of positive correlations established in leadership research. Successful leadership has been linked to, for instance, increased work morale and well-being (Alvesson et al., 2017); strengthened self-esteem (Mhatre and Riggio, 
56 (Parker and $\mathrm{Wu}, 2014$ ); and an accentuated sense of meaning related to a collective organizational vision (Alvesson and Spicer, 2014). Translated to the organizational levels, it has furthermore been shown that leadership can explain a substantial degree of performance variances (Day and Lord, 1988, see also Wang et al., 2011), as well as being a potent nostrum for organizational development and change (Bass and Avilio, 1993; Nadler and Tushman, 1994; Appelbaum et al., 1998; Yukl, 2002; Kisfalvi, 2002; Gilley et al., 2009).

62

Considering this, there is a curious absence of a matured leadership agenda in construction research. The construction industry is continuously criticized for its lack of performance regarding a broad pallet of areas. Governmental reports in numerous countries have concluded that the construction industry suffers from excessive production costs, low efficiency, slow delivery, and failure to innovate, among other things (see Chan and Cooper, 2010 , for an overview). Grounded in this criticism, construction research is rich in contributions of how the industry should transform according to improved structures, processes, technologies, materials, and management concepts, not seldom adopted and translated from other industries and contexts. Yet have leadership perspectives seldom been adopted to frame and explore the specifics of these industry conditions and challenges.

Reviewing and reflecting on the accumulated insights drawn from leadership studies in construction research, it is possible to identify an urgent gap, which can be inferred from a lack of methodological variation. As it will be argued in the next section, leadership has been explored with a salient proclivity towards testing quantitatively the ideas and models of leadership scholars, rather than to explore qualitatively the experiences of the actual people that might or might not practice leadership in their daily work in the construction industry. This methodological homogeneity has resulted in a lack of studies that incorporate the 
various "extraneous factors" of leadership (Alvesson and Spicer, 2014) that are embedded on the industry-, organizational-, and day-to-day local levels, and condition the nature of leaderfollower interactions (Liden and Antonakis, 2009). This has left a blind spot, not only regarding how the specifics of various construction contexts shape leadership processes, but also how leadership might shape construction.

87 The purpose of this paper is to provide an initial filling of this gap by exploring the tensions and alignments that underlie the ongoing uptake of leadership in a situated construction context. Adopting a qualitative methodology, this paper draws on rich stories about leadership in large construction companies in Sweden. These stories were collected and analyzed specifically to highlight the recursive dynamics between leadership and the specific conditions and challenges that underlie managerial work in these companies. The results show a growing appreciation and adoption of certain 'modern' leadership practices, as portrayed in contemporary leadership research. However, with that said, the actual uptake and enactment of these practices seem to lack much of the alleged potential of leadership as a transformative force. The results show instead how the ongoing adoption of leadership also seems to work to sustain (and even further reinforce) traditional work- and organizing practices in these companies, not the least by providing mandate and socially mediated governance for a high degree of independence and freedom in the management of various construction tasks. In addition to this, the results also illustrate a certain tension between the identified leadership styles and an ongoing strive to increase organizational performance by developing and implementing more standardized processes and routines. The paper concludes by outlining the practical implications of these results and elucidating further the analytical generalizations that can serve as pointers for a strengthened leadership agenda in construction research. 
THEORETICAL AND METHODOLOGICAL (RE)ORIENTATION

\section{Towards a situated understanding of leadership in construction}

109 Over 25 years ago, Langford et al. (1995) noted a substantial shortage of leadership studies in

110 construction research and argued that this might be explained by the lack of understanding of

111 the industry on the part of social scientists and a lack of understanding of the social sciences

112 on the part of those engaged with the industry. While leadership studies in construction have

113 been slowly growing since then (Toor and Ofori, 2007), it appears as if the argument still

114 holds insofar as the contributions reflect a dominant research tradition in construction that is

115 grounded in quantitative and positivistic methods, rather than the methodological richness

116 that characterizes the social sciences (Dainty, 2007; Dainty, 2008; Fellows, 2010; Sage and

117 Vitry 2018). A scrutiny of the studies that brought the topical area of leadership into

118 construction research shows a prominent preference for research designs and methods that

119 rely on quantitative testing of established leadership models, such as Fiedler's Contingency

120 Model (Bresnen et al.,1986; Seymour and Abd Elhaleem, 1991), Fiedler's LPC questionnaire

121 (Fellows et al., 2003), BARS (Dulaimi and Langford, 1999), the MLQ model (Chan and

122 Chan, 2005; Butler and Chinowsky, 2006; Ozorovskaja et al., 2007), the MSQ model (Giritli

123 and Oraz, 2004), or the Kouzes-Posner Leadership Practices Inventory (LPI) (Skipper and

124 Bell, 2006).

126 The point here is not to argue for the strengths and weaknesses of different methodological

127 approaches, but how a certain methodological homogeneity by the part of construction

128 researchers (Dainty, 2008) seems to have resulted in a gap in our understanding of the

129 specific characteristics and meanings of leadership in a construction context. While the

130 preference for large data sets and closed-question questionaries supports both the reliability 
131 and generalizability of the causalities found in relation to leadership (Taylor et al., 2010), it

132 has consequently also downplayed our understanding of the meaning and experience that the

133 actors themselves assign to leadership in relation to their daily work in construction (McCabe

134 et al., 1998).

135

136 Toor and Ofori (2008) argue for the need to strengthen the leadership agenda in construction

137 by moving beyond the "conventional transactional mentality and task-orientation of industry

138 professional" (ibid: 620), towards an accentuated focus on inter-personal skills and relations,

139 such as leadership. However, it appears as if the shifting focus from task-based to person-

140 based perspectives not merely has served as the starting point for leadership studies in

141 construction, but also to some extent the reoccurring conclusions. Whether the focus has been

142 on construction projects (Bresnen et al., 1986; Seymour and Abd Elhaleem, 1991; Fraser,

143 2000; Fellows et al., 2003) or organizations in the construction industry more broadly

144 (Dulami and Langford, 1991; Odusami et al., 2003; Chan and Chan, 2005; Kasapoğlu, 2014),

145 it is possible to discern a certain converging and general conclusion that an increased

146 attentiveness to inter-personal relations, on top of construction tasks, is correlating positively

147 with increased performance in various construction operations.

149 However, this correlation seems not only to be generalizable across several different

150 construction contexts but is also reported in meta-analyses of a broad range of other contexts

151 and industries (Wang et al., 2011). Rather than being concerned about the generalizability of

152 the leadership-related causalities found in construction contexts (e.g., Odusami et al., 2003;

153 Chan and Chan, 2005; Kasapoğlu, 2014), it seems timely to also problematize them for being

154 too general; and for merely reiterating the general ideas and promises of leadership, without 
offering any detailed understanding of how leadership have been conditioned by the specifics of construction (and vice versa).

158 Such an understanding is essential, not least because there exists no shared and stable

159 definition of leadership (Bass, 2008). Every attempt to provide or reuse a concise leadership

160 definition is deemed to leave something out or oversimplify what, in reality, is a complex, 161 dynamic, and evolving process (Day, 2014). The growing number of construction scholars

162 (e.g., Chan and Chan, 2005; Butler and Chinowsky, 2006; Ozorovskaja et al., 2007;

163 Kasapoğlu, 2014) drawing on the seminal transactional and transformational models of

164 leadership (e.g., Bass and Avolio, 1994; Bass and Riggio, 2006; Diaz-Saenz, 2011) are,

165 therefore, not only adopting a preconceived definition of leadership but also assume that

166 'leadership' is encapsulating almost every activity that various managers in a construction

167 setting are performing in their work. Those that are critical of such reuses of ready-made

168 leadership definitions and frameworks argue that if 'leadership' is used uniformly to describe

169 a broad range of different managerial activities, we risk serious inflation in the meaning (and

170 value) of leadership, not least by making it indistinguishable from 'management' in general

171 (Alvesson and Spicer, 2012). A more situated understanding of leadership is therefore not

172 only to acknowledge that leadership is largely shaped by its surroundings, but also that

173 leadership is only one out of many other organizing principles that managers have at their

174 disposal when trying to navigate their organizational realities (Alvesson et al., 2017).

176 The overreliance on quantitative testing of ready-made leadership models and perspectives on

177 the part of construction researchers seems to have produced such lack of nuances in our

178 understanding of leadership in the construction industry. Prioritizing preconceptions about

179 leadership before the actor's own interpretations of their experiences from practicing 
leadership (Alvesson and Spicer, 2014) have, altogether, placed the actual persons that engage in these inter-personal relations as being detached from the specifics of the context they are acting in (Barker, 2001). To start addressing this gap, it is therefore essential to view and explore leadership in the construction industry as a processual undertaking, involving

184 leaders, followers, and several contexts in an ongoing interaction of co-operation, collaboration, and co-creation, accomplished over time through enacted processes, situated practices, and dialogue (e.g., Bolden and Gosling, 2006; Carroll, 2008; Crevani et al., 2010;

187 Cunliffe and Eriksen, 2011; Bolden et al., 2011; Alvesson and Spicer, 2014; Collinson et al., 2018).

Understanding leadership as a social process that is being imbued with meaning when it is enacted in context also reminds us about the recursiveness between leadership and context. Paying closer attention to how leadership - the verb and not the noun (Crevani et al., 2010) -

193 has been shaped by, but also might shape, various aspects of the construction context, might

194 also support an extension of the gaze beyond the linkages between leadership and current construction operations, to encompass also an understanding of leadership processes embedded in a trajectory that permeates the past, the present, and the future of the construction industry (Chan and Cooper, 2010).

199 Rather than offering any detailed theoretical framing, the arguments put forward here are bridging over to a general methodological reorientation. To prioritize situated interpretations of leadership (Alvesson and Spicer, 2014) in construction, this paper follows the methodological assumptions that underlie qualitative studies of leadership (Bryman, 2004;

203 Fairhurst, 2007). Therefore, the next section elaborates these arguments with details about the 204 design of a qualitative interview study of leadership in construction companies. 
RESEARCH DESIGN AND METHOD

This paper draws on data from 24 in-depth and open-ended interviews about leadership conducted with middle- and top-level managers in the largest construction companies in

210 Sweden. The purpose of the study was to explicitly foreground the managers' own

211 interpretations of leadership processes as they unfold in these particular organizations, rather

212 than testing any pre-existing leadership models, definitions, or hypotheses. We, therefore,

213 designed an interview study grounded in an explorative and inductive research methodology.

214 The interviews were carried out during 2020 and included middle- and top-level managers

215 from the six largest (measured in turnover) construction companies in Sweden. This paper

216 identifies these companies using the pseudonyms ConstraCORP, ConstructINC, ConcrETE,

217 ContraORG, ConstructION, and ConSTRUCT. The interviewees will be referred to as

218 "managers" instead of "leaders" throughout the paper. This is to reflect a central tenet of the

219 research, under which leadership is considered a distinct social process as opposed to the

220 formal role of being an appointed manager (Alvesson et al., 2017). The 24 managers were selected equally across the six companies (i.e., four from each company) and included the following formal positions: Regional Manager $(n=6)$, Division Manager $(n=4)$, Project Manager $(n=3)$, District Manager $(n=2)$, Business Area Manager $(n=2)$, Development Manager $(n=2)$, Site Manager $(n=2)$, Production Manager $(n=1)$, Marketing Manager $(n=$ 1), HR-Manager $(\mathrm{n}=1)$.

227 When selecting these interviews, several different sampling criteria were considered. The

228 first consideration was to select interviewees from several different construction companies to explore any possible variations in leadership. However, as the study progressed, we found 
230 striking similarities across the companies, suggesting that the study might best be

231 characterized as a single case study (Flyvberg, 2006) of leadership in large construction

232 companies in Sweden. The minor variations found are outlined in the result section. Still,

233 they also strengthen the idea that leadership processes in construction companies may overlap

234 with a certain community of practice (Dubois and Gadde, 2002).

235 A second consideration regarded which managers to select for interviews. We decided to

236 include a mixture of managers from both the line organization and the central functions.

237 Under this general idea, the managers were selected according to a snowballing principle,

238 which provided us with an interesting sample. Not the least since the managers tended to

239 direct us further, either to the manager immediately above or below them in the hierarchy.

240 Based on this, the interview data provided us with the possibility to triangulate their stories

241 about leadership by comparing different versions of the leader-follower processes as they

242 permeate various organizational levels.

244 The third consideration was how many interviews to conduct. Here we were guided by an

245 overall sensitivity to an ongoing degree of saturation concerning the content of the leadership

246 narratives collected (Patton, 2002); that is, we conducted additional interviews until no or

247 very few additional insights were deemed to follow from yet another interview. While there

248 is no universal number for when saturation in qualitative interviewing usually occurs,

249 research suggests that 24 interviews would fall well within the critical scope (Guest et al., 250 2006).

251

252 During the interviews, we let the managers act as free storytellers (Cladinin and Connelly, 253 2000) as much as possible. In this case, collecting open-ended stories about leadership were 254 considered to support a receptiveness for the links between experience and meanings related 
to leadership and the particularities of the contexts in which these meanings are constructed

256 (Cladinin and Connelly, 2000; Gill, 2001; Alvesson and Sköldberg, 2017). Instead of

257 following a detailed interview guide, we probed the managers to tell their stories across a

258 number of interrelated themes (see Table 1).

[INSERT TABLE 1 HERE)]

Table 1. Overview of the overarching themes used in the interviews.

The managers typically covered most of the themes using their own narrating, although not always in the order presented above and often in a more interrelated and overlapping fashion. The interrelation between the themes, were, in fact, commonly used as a cue for our followup questions. As were brief follow-up questions asking "why?..why?..why?", "can you explain further?", and "can you give a concrete example?", all to support the overall research ambition to understand leadership as it was related to the daily work of these managers. Each interview lasted between 60 and 90 min and was recorded and transcribed verbatim, amounting to $18-30$ A4 pages of written text.

274 ANALYSIS

275 The interview transcripts were analyzed in three phases: (1) open coding, (2) axial coding, and (3) selective coding (cf. Strauss and Corbins, 1990). With the inductive approach as a starting point (Thomas, 2006), the analytical process was inspired by the general intentions and guidelines within Grounded Theory, but without strictly following all the steps outlined by Strauss and Corbin (1990). Instead, the aim was to maintain, as far as possible, an open 
mind for different interpretations of leadership and thus joining the more interpretative approach of Strauss and Corbins (1990), Czarniawska (2004), and Charmaz (2006) to the analysis of interview data; seeking to create a coherent story that captures the meaning of the situated events.

Following this, the three analytical phases overlapped in multiple step-based readings of the material and iterations between the data set and emerging findings (Alvesson and Kärreman, 2011), as well as ongoing joint discussions between all the authors of this paper, to strengthen the validity of the interferences made (Taylor et al., 2010). The first rounds of readings were open, searching for any interesting patterns of consensus and/or variances concerning leadership. After this initial reading, we focused on phase 1, collecting a wealth of open codes (Strauss and Corbins, 1990) that captured the most central aspects of the interviewees' leadership narratives. Considering the explorative nature of this study, there were no preconceptions and/or hypotheses about leadership that were deemed suitable to pre-code using any software (such as NVivo). Instead, we conducted this step as a very timely manual endeavor, guided by the overall themes described in Table 1. This resulted in four thematic clusters of open codes, including the importance and role of leadership (see Category A, Table 2), leadership styles and perspectives (Category B), alignments between leadership and current organizational principles (Category $\mathrm{C}$ ), and tensions between leadership and future organizational principles (Category D). In this phase, we also searched for open codes

300 concerning 'leadership training' and 'origins of leadership', but found too few descriptions to 301 proceed with these open codes in phase 2) and 3).

303 Phase 2) and 3) of the analysis sought to investigate and conceptualize the relationship

304 between the concepts identified in the open coding process. Here we drew directly on Strauss 
and Corbin (1990) and treated the difference between the Axil codes and the Selective code merely in terms of an increased level of abstraction (with the Selective code being the overall

307 Result category). Again, these phases involved a lot of re-reading of the material to validate

308 the emerging Axial and Selective codes against the contextual use and meaning of the Open

309 codes found in the interview transcripts (Strauss and Corbin, 1990). A detailed overview of

310 the three analytical phases is outlined in Table 2 below, followed by a result section that

311 presents and explains both the meaning and the interrelations between four core categories of

312 leadership processes found in the construction companies studied.

[INSERT TABLE 2 HERE]

Table 2. A detailed overview of the analytical process

\section{RESULTS}

\section{Adding leadership on top of construction expertise}

319 When describing the details of the professional profiles that had qualified them for their current positions, the vast majority of the managers emphasized the importance of construction expertise and experience. The results elucidated that this view echoed across all the various managerial positions and echelons because it reflected a certain logic relating to the career progression in these companies.

Every project is unique, and you, therefore, have to adapt to unique circumstances... this requires a very specific set of skills and experience. Therefore, to qualify for the highest positions in a construction company...say, for instance, regional manager... you need to have experience from these all steps... those promoted to regional 
managers have vast experience from all the different steps of the hierarchal ladder.

332 Leadership skills were also perceived to be important, but only on top of construction-

333 specific expertise and experience.

An extensive construction experience is needed indeed...that you have experience from various positions. I mean, we have this career progression ... it is not 100 precent like this, but the majority of the highest positions, like regional managers, have been district managers before, and before that project managers. But great leadership skills are also required to manage both customers and employees in a good way. (Manager 4, Regional Manager, ConstraCORP)

However, the general view that leadership skills were perceived as being of secondary importance was often expressed in a self-ironic and critical fashion.

In that regard, I think we distinguish ourselves a bit [construction companies compared to other companies] ...we have too many engineers that have become leaders or managers...that might not necessarily be the best leaders. I believe that our sector has a lot of work to do in relation to this. To start promoting the best leaders, rather than only the best engineers. (Manager 6, Development Manager,

And: 
I really hope that the construction industry can start to value leadership more. It is

360 While many of the managers were critical regarding the overly relaxed pace of increasing the

377 With that said, it was possible to find in the data a more quantitative measurement that

378 indicated that leadership, despite this perceived transition, has yet to become a prioritized 
concern for managers in construction companies. Be means of distilling all the narrative passages that addressed the managers' professional backgrounds, we found that 20 out of the 24 managers have worked their whole careers in construction companies, and only four have been recruited from outside (see also Table 2). These figures indicate that construction expertise still trumps leadership skills when these companies appoint their managers, including the top echelons. Put differently; in the sample of our interviews, few, if any, managers have been recruited solely based on their leadership skills. This homogeneity that permeates the managerial profiles seems furthermore to translate into certain collective views on leadership, as highlighted in the next section.

\section{Responsive leadership}

390 The managers generally perceived leadership as a distinct set of practices rather than 391 anything that per default was encapsulated in their formal roles. In fact, they marked a clear 392 distinction between "management" and "leadership", in which the former had to do with

393 formal procedures and processes, tasks, and bureaucracy, and the latter with inter-personal

394 relations. We also learned that they generally associated leadership with a positive connotation and management with a negative one.

397 By far, the most frequent description of the managers' leadership perspectives and styles was responsiveness. Responsiveness is the English translation of the Swedish word "lyhörd",

399 which according to the dictionary is defined as "to readily apprehend and pay regard to something". In the manager's stories, responsiveness was used both directly as a keyword

401 and as a central general perspective to describe a leadership style characterized by carefully

402 listening to their employees to understand their personal needs related to work and then trying 403 to accommodate those needs (see also Table 2, for a detailed overview). 

responsive to their needs [the followers]. I really like to talk to and meet with people. I care a lot about them enjoying their work ... and that we have fun together. (Manager

410 Another: My leadership style is to listen carefully to people ... and to provide them with the right

417 A central tenet of leadership-as-responsiveness was to take seriously the idea that each person 418 is different and then adapt to these differences. The results highlight how the managers have 419 developed the skills required to adapt to all the different and unique construction management tasks and all the different and unique employees. Leadership as responsiveness thus encapsulates a type of situation-based work approach applicable for both people and tasks.

I practice a very situation-based leadership, and I am good at responding to the situation I am in... both to different situations and different people. The benefits of this are that I tend to get both employees and customers on my side. (Manager 9, 
428 When asking them to describe what kind of skills are needed to be a responsive leader, the managers used examples such as "people skills", "communication skills", "being like a psychologist", "being like a friend". However, it was also common for them to emphasize the advantages of having vast construction experience, thus linking their leadership styles to the managerial ideals highlighted in the previous section. responsiveness, then I mean to understand the realities of the people you are leading. [...] In my view, a successful middle manager, for instance, should have the ability to do the site manager's job if needed... and a site manager, in turn, should be able to be a team leader and so on. If you have those abilities, then you can truly understand the realities and challenges of those you are leading .... and then I think it is much easier

A question that lingered as the researchers listened to these descriptions of responsive leadership was how it aligns with the kind of organizing that might require more top-down directions.

Manager: First of all, you have to really listen to people. I need to understand what they really feel about the initiatives I am proposing. The key is then to nudge wisely... and entice carefully. To make [naming a subordinate] really want to use whatever I am proposing in their work. No one will buy into changes if they think I am being too 
454 Leadership as responsiveness seemed to be aligned with a permeating idea of not telling other experienced workers how to do their job. This relation could thus explain how leadership has become embedded in some of the specific conditions in these construction companies.

\section{The alignment between leadership and current organizing principles}

The results indicate that the responsive leadership styles are aligned with ongoing processes of delegating tasks and responsibilities down the organizational levels. In addition to "dictatorship" as a contrasting ideal, the managers also frequently used the idiom of "pointing with the whole hand" as a more detailed account of how they didn't want to lead. While the managers stressed that they had no problems making tough decisions when needed, this was considered only as an exception to an overall status quo of passing down a high degree of freedom and responsibility downwards the managerial echelons.

Manager: I really don't want to be the kind of leader that is pointing with the whole hand.

Researcher: Ok, but how do you organize and direct your employees then?

Manager: As little as possible. I have always had a problem with those managers that want to intervene with what I do and how I do it. Therefore, I just explain the task, and when the deadline is... and after that, I try to intervene as little as possible in their [the followers] work towards that goal. Being too detailed about how to do things kills creativity. I mean, if I were to tell my employees how they should do their jobs 
that is very value-adding for the person either. It is people that do this job after all.

481 As this example shows, the idea of mandating high degrees of freedom was a reciprocal process, as this manager expected the same degrees of freedom from his [sic] manager. The common leadership styles were thus embedded in a permeating organizing principle that mandated the rather homogenous group of skilled and experienced construction managers to perform their work within very free realms. This dominant principle was readily confirmed when the managers reflected on the differences between leadership in construction compared to other contexts.

Here [in construction companies], you are delegated a lot of responsibility and freedom to do what you want. It is actually an enormous amount of freedom that is given to you. My wife is working in a very high position in the car industry... and I have learned from her that they are far more micro-managed than we are [in construction companies]. We are pretty bad at processes...we reinvent the wheel and all that ...but we are highly skilled at problem-solving...because we are constantly given these high degrees of freedom and responsibilities. And I must say that this is a really exciting aspect of this line of work. (Manager 2, Project Manager, ConstraCORP)

The freedom in work governed by their leadership perspectives and styles seemed also to span beyond the rational domains. Scrutinizing their explanations, we also found many more emotionally laden accounts linked to these permeating logics. 
I don't know for sure, since I never worked outside construction ...but my view is that the car industry, for instance, seems to be much more structured and micro-managed, compared to construction. [...] and I don't think many of us working in construction could handle to work in any other industry, just because the degree of control would

509 be so much higher. We are just so used to 'navigate our own ships'. (Manager 7, Project Manager, ConstructINC)

The preferred leadership styles were thus related both to the organizational tasks per se and a

513 When the managers reflected on the differences between leadership in construction and other industries, almost all of them used the car industry as their comparative example. As it turned out, one of four managers (see Table 2) that had been recruited from outside of construction had actual experience from working in a large international car manufacturer and could

517 therefore readily confirm the collective perceptions. The work is very unstructured here in ConstructINC compared to the car industry [...] That is actually a big difference for me... how unstructured the work is here [in construction]. I am actually surprised that it is even possible to run operations in such an unstructured way as we do here... and I cannot help thinking about how extremely well we could do and how much money we could make if only we had more structure. These circumstances are actually a major challenge for me as a relatively inexperienced leader in construction (Manager 5, Production Manager, 
528 While confirming the differences, this manager viewed them in a much more critical manner.

529 Rather than positively associating the lack of structures with personal freedom embedded in

530 professional work, this manager conceived of the general leadership styles as posing a

531 threshold for increased organizational performance.

532

533 The tension between leadership and future organizing principles

534 The results offer snapshots of how certain leadership styles have gradually aligned with the overarching organizing principles in the construction companies studied. However, the results also point out a salient tension in relation to ongoing organizational transformations.

We have this strong tradition in construction of a very decentralized structure and extremely high levels of autonomy related to project management... and how these 'strong heroes' manage the end results in their own individualized ways. But I think that we here at ConstraCORP, as well as ConstructING and ConstructION, now have started to become much more centralized and structured, compared to other construction companies [...]. But even when having all these structures, business models, and process .... this old logic still remains strong. (Manager 3, Development

547 The manager in this example refers to an ongoing change that is contrasting the leadership

548 processes that govern delegation of individual freedom and personalized problem-solving.

549 While the results point to a collective set of preferred leadership styles, they also capture several contrasting accounts regarding the future. Among those are accounts that testify to another ongoing change relating to the implementation of more structures, processes, and collective routines, altogether following a more standardized top-down type of organizing 
that is grounded in an overarching strive to improve organizational performance (see also

554 Table 2, for an overview of these accounts).

555

556 The results show that the managers seemed to be unwillingly aware of this and that it evoked

557 a lot of emotions. Next follows a series of three quotes from three different managers, all

558 working in one of these companies, independently reflecting on these issues.

559

560 The first, Manager 9, now working in ConcrETE, but having experience also from

561 ConstraCORP, is voicing this in a critical manner:

562

563

564

565

566

At ConcrETE, it is the people that are the most important part of the company. They are the ones that are doing the job... and represent the 'entrepreneurs within all of us'. This differs from my experience working at ConstraCORP, where they tried to 'cast us all in the same mold'. (Manager 9, Division Manager, ConcrETE)

567

568

Another, Manager 10:

569

570

Here at ConcrETE, we are down to earth, and we are personal. ConcrETE isn't like ConstraCORP, for instance... we are more soft and more human I would say. We are not nearly as top-managed here. Of course, we still have our own structures and routines, but I believe these are not as strict as in other construction companies... and that is just the way we like it here at ConcrETE. We have actually been paying a lot of attention to preserve that specific aspect of work (Manager 10, Regional Manager, 
And another, Manager 12:

579

580

581

582

583

584

585

586

587

588

591

592 In one of the previous sections, we presented an account from a manager that worked in

593 ConstraCORP and positively proclaimed how much freedom and maneuvering space was delegated to you in construction, compared to other industries. While in this section, managers that worked for ConcrETE positively proclaimed the same, but when comparing to ConstraCORP. Manager 12, from the last example here, was, however more ambiguous, and pointed instead to the smaller construction companies as the true realms for the much valued and traditional 'professional freedom'. However, the variations found were only differing in scale and not in terms of the main characteristics they highlight. Altogether, they lend weight to certain leadership styles that gradually - from the past to the present - have aligned with

601 the dominant organizing principles in these construction companies. But now - going from 602 the present to the future - these seem to pose an unresolved tension with ongoing (albeit 
seemingly slow) organizational transformation intended to improve construction management

604 and organizing.

605

\section{DISCUSSION}

607 The results of this paper show that managers in construction companies view 'leadership' as a

608 distinct set of principles and practices that they use, to varying degrees, in their day-to-day

609 work. One such clear distinction was how the managers perceived of leadership as belonging

610 to the 'person-based' domains of their work, as opposed to the 'task-based' domains under

611 which they sorted all activities more directly related to the formal construction management

612 and organizing (cf. Bass and Avolio, 1994; Conger and Kanungo, 1998; Yuk1 2006;

613 Northouse, 2016).

614

615 With that said, the managers also testified to overlaps between these two domains:

616 emphasizing a salient alignment between their leadership styles and the inherent nature of

617 their managerial tasks. Most notable is how 'responsiveness' - sensing and adapting to a

618 constant stream of ad hoc challenges - was applied as a central principle for both their

619 leadership of people and management of tasks. While this could point to a certain reciprocal

620 alignment between project-based organizing and leadership (Tyssen et al., 2014) in

621 construction companies, the results also remind of the need to critically scrutinize the

622 underlying mechanisms of this dynamic; not least to understand to what extent leadership is

623 transforming or being transformed by the situated organizational context at hand (e.g.,

624 Crevani et al., 2010; Cunliffe and Eriksen, 2011; Bolden et al., 2011).

625

626 Even though leadership gradually seems to have received increased attention in the

627 construction companies studied, it is still clearly being overshadowed by certain pervasive 
managerial ideals relating to the significance of having profound experience and expertise of

629 construction - that is, being foremost task-oriented. The results suggest that the uptake and

630 legitimacy of leadership practices are largely preconditioned by embedded practices that are

631 linked to these dominant ideals; more specifically, it appears as if leadership has foremost

632 been adopted and enacted to strengthen and sustain traditional work and organizing in these

633 construction companies, rather than being used to change and improve it. This is most notable

634 in relation to how the collective leadership styles serve to broadly govern and mandate a

635 multi-level pattern of delegation of free and independent work, under which the homogenous

636 group of "construction experts" continue to work according to their own best practices. This

637 finding resonates well with previous studies that have explored the uptake of other change

638 and development-oriented practices in construction companies, such as strategic plans

639 (Löwstedt and Räisänen, 2012), strategy workshops (Löwstedt et al., 2018), and innovation

640 management (Nam and Tatum, 1997); altogether concluding that such 'exogenous' practices

641 tend to be downplayed and shaped by existing 'indigenous' managerial practices, rather than

642 having much success changing them.

643

644 While leadership seemed to have been adopted to align with current construction

645 management and organizing, the results also point out apparent tensions in relation to

646 envisioned future states. Table 2 (category 4) lists the most pressing organizational

647 challenges for construction companies, as perceived by the interviewed managers; elucidating

648 a permeating need to transform organizing and management principles to support more

649 efficient and standardized organizational processes (to, ultimately, increase construction

650 production performance). This puts into serious question the appropriateness of leadership

651 styles geared foremost to be responsive to support and govern the individualized freedom and

652 independence that construction experts have grown accustomed to. 
654 Altogether, this study points to a lot of internal ambiguity regarding the role that current

655 leadership styles might play to transform construction. Instead of trying to advocate for one

656 preferred leadership style, the results are rather pointing to the fact that this ambiguity is best

657 to be unpacked by paying more critical attention to the variances of leadership in

658 construction. The results suggest that the homogenous leadership styles practiced by the

659 managers can be linked to their homogenous professional backgrounds and profiles.

660 Following the lead of the few critical voices represented in the result section might, therefore,

661 offer an important reminder to start to question, or at least further explore, the dominant

662 views that seem to have established that the preferred leadership styles in construction

663 companies (for all managerial echelons) are those that are well aligned with current

664 construction organizing practices, rather than those that might challenge and transform them.

665 For change in construction, it might therefore be beneficial to have among the homogenous

666 group of 'responsive listeners', a manager that, at least occasionally, is leading in new future

667 directions, 'using the whole hand'.

668

\section{CONCLUSIONS}

670 A growing number of construction researchers have pointed at a positive correlation between

671 leadership and enhanced performance in various dimensions in the construction process - as

672 it is currently organized. This study can conclude that certain distinct practices related to

673 leadership indeed are perceived to be of great importance for achieving high performance in

674 the work as a manager in construction companies. However, it can also be concluded that

675 these same leadership practices seem to preserve status quo in these companies, rather than

676 supporting change and development. The positive correlation between leadership and

677 performance is thus much more questionable, if considered from a long-term perspective. The 
678 clearest example drawn from this study, is how current leadership processes pose a seemingly

679 unresolved tension with change initiatives that seek to improve organizational performance

680 by means of reorganizing construction companies according to more streamlined and

681 standardized processes. It is suggested that this preserving leadership effect can be linked to

682 the high (maybe too high) degree of homogeneity that permeates both the leadership styles

683 and the professional backgrounds of the construction managers practicing leadership.

684

685 GENERALIZABILITY AND FUTURE STUDIES

686 This study was predicated on the need for a deepened understanding of how leadership

687 processes relate to the specifics of construction. Based on this, the study was deliberately

688 designed to foreground in-depth meanings over general causality. Because of this, there is an

689 inherent limit to the generalizability of the findings. While the level of saturation would

690 suggest that the results serve to represent situated leadership characteristics in the largest

691 construction companies in Sweden, many different variations are to be expected, for instance,

692 in construction companies operating in other countries. This is however not mainly related to

693 the qualitative methodology used, but rather to the fact that it is well established that

694 leadership ideals and practices differ significantly across cultural contexts (see Brodbeck and

695 Eisenbeiss, 2014, for a review of this extensive field of studies). It is, therefore, unsurprising

696 that studies that have tested leadership variations across cultural contexts in construction

697 specifically have, indeed, found such differences (Giritli and Oraz, 2004; Mäkilouko, 2004;

698 Wong et al., 2007; Kasapoğlu, 2014).

699

700 Our case, drawn from the Swedish context, shows how the ongoing adoption of 'modern'

701 leadership ideals in construction companies is ridden variously with both alignments and

702 tensions. 'Modern' could be seen as denoting contemporary perspectives of leadership, as it 
703

704

705

706

707

708

709

710

711

712

713

714

715

716

717

718

719

720

721

722

723

724

725

726

is portrayed both in leadership research and popularized discourses; that, at least in Sweden, are foregrounding people before tasks, coaching and listening before directing and telling, and informal empowerment before formal and more coercive power. Seeing the increased interest and adoption of such 'modern' leadership ideals happening in an industry that is often criticized for being 'unmodern', could indeed be interpreted as a promising sign. However, zooming in on the details of these processes indicates that the transformative potential of leadership appears to be disappointing in these construction companies. Rather than a sign of inconclusiveness, these findings reflect the inherent dynamics that underly the local enactment of leadership as a certain social practice that never solely (or maybe not even mainly) is invented 'in-house', but is also embedded on the level of societies, as various national and cultural versions.

A strengthened leadership agenda in construction research would be characterized by a detailed understanding of the differences between general relations and variations of leadership and those that can be linked specifically to the situated construction context. By prioritizing the detailed meaning of leadership processes in construction companies, this study offers analytical rather than statistical insights (Taylor et al., 2010; Yin, 2013). Therefore, the value of the findings in this paper is not mainly to be judged by how well they represent an objectified and general reality of leadership in construction, but rather by which consequences they produce (Ellis and Bochner, 2000). One such fruitful consequence would be a future stream of leadership studies by construction researchers that are characterized by an enhanced methodological richness, variously prioritizing both rigor and relevance. 
Some or all data, models, or code that support the findings of this study are available from the corresponding author upon reasonable request.

\section{REFERENCES}

Alvesson, M. and Kärreman, D. (2011). Qualitative Research and Theory Development: Mystery as Method, Sage Publications, London.

Alvesson, M. and Sköldberg, K. (2017). Reflexive Methodology: New Vistas for Qualitative Research, Sage Publications, London.

Alvesson, M. and Spicer, A. (2012). Critical leadership studies: The case for critical performativity. Human relations, 65(3), 367-390.

Alvesson, M. and Spicer, A. (2014). Critical perspectives on leadership. The Oxford handbook of leadership and organizations, 40-56.

Alvesson, M. and Sveningsson, S. (2003). Managers doing leadership: The extraordinarization of the mundane. Human relations, 56(12), 1435-1459.

Alvesson, M., Blom, M. and Sveningsson, S. (2017). Reflexive leadership: Organising in an imperfect world. SAGE Publications Inc.

Antonakis, J. (2012). Transformational and Charismatic Leadership. In D. V. Day \& J. Antonakis (Eds.), The nature of leadership (2 ${ }^{\text {nd }}$ ed., pp. 256-288). Thousand Oaks, CA: Sage. highly cited?. The Leadership Quarterly, 25(1), 152-179. 
Appelbaum, S. H., St-Pierre, N., and Glavas, W. (1998). Strategic organizational change: the role of leadership, learning, motivation and productivity. Management Decision, 36(5), 289301.

Barker, R. A. (2001). The nature of leadership. Human Relations, 54(4), 469-494.

Bass, B. M. and Avolio, B. J. (1993). Transformational leadership and organizational culture. Public administration quarterly, 112-121.

Bass, B. M. and Riggio, R. E. (2006). Transformational leadership. Psychology press.

Bresnen, M. J., Bryman, A. E., Ford, J. R., Beardsworth, A. D. and Keil, T. E. (1986). Leader orientation of construction site managers. Journal of Construction Engineering and Management, 112(3), 370-386.

Brodbeck, F. C. and Eisenbeiss, S. (2014). Cross-cultural and global leadership. In The Oxford handbook of leadership and organizations.

Bryman, A. (2004). Qualitative research on leadership: A critical but appreciative review. The leadership quarterly, 15(6), 729-769.

Butler, C. J. and Chinowsky, P. S. (2006). Emotional intelligence and leadership behavior in construction executives. Journal of management in engineering, 22(3), 119-125.

Chan, A. T. and Chan, E. H. (2005). Impact of perceived leadership styles on work outcomes: Case of building professionals. Journal of construction engineering and management, 131(4), 413-422.

Chan, P. and Cooper, R. (2010). Constructing Futures: Industry leaders and futures thinking in construction. John Wiley \& Sons.

Charmaz, K. (2006). Constructing grounded theory: A practical guide through qualitative analysis. Sage. 
790 Cladinin, D.J. and Connelly, F.M. (2000). Narrative Inquiry: Experience and Story in

791 Qualitative Research, Jossey-Bass, San Fransisco.

792

793 Conger, J. A. and Kanungo, R. (1998). Charismatic leadership in organizations. Thousand

794 Oaks, CA: Sage.

795

796

Czarniawska, B. (2004). Narratives in Social Science Research, Sage Thousand Oaks, CA.

797

798

Dainty, A. R., Cheng, M. I. and Moore, D. R. (2005). Competency-based model for

799

predicting construction project managers' performance. Journal of Management in

800 Engineering, 21(1), 2-9.

801

802 Dainty, A. (2008). Methodological pluralism in construction management research. In:

803 Knight, A., and Ruddock, 622 L. (eds.). Advanced research methods in the built environment.

804 Chichester: Wiley-Blackwell, 1-13.

805

806

Dainty, A. (2007). A review and critique of construction management research methods, in

Hughes, W. (ed.) Proceedings of Construction Management and Economics 25thAnniversary

808 Conference, University of Reading, 16-18 July, p. 143

809

810 Day, D. V. (2014). Introduction: Leadership and organizations. In D. V. Day (Ed.), Oxford

811 library of psychology. The Oxford handbook of leadership and organizations (p. 3-12).

812 Oxford University Press.

813

814 Day, D. V. and Lord, R. G. (1988). Executive leadership and organizational performance:

815 Suggestions for a new theory and methodology. Journal of management, 14(3), 453-464.

816

817 Diaz-Saenz, H. R. (2011). Transformational leadership. The SAGE handbook of leadership, 818 5(1), 299-310.

819

820 Dubois, A. and Gadde, L. E. (2002). The construction industry as a loosely coupled system:

821 implications for productivity and innovation. Construction Management and Economics, 822 20(7), 621-631. 
824 Dulaimi, M. F., and Langford, D. (1999). Job behavior of construction project managers:

825 determinants and assessment. Journal of Construction Engineering and Management, 125(4), $826 \quad 256-264$.

827

828 Duman, D. U., Green, S. D. and Larsen, G. D. (2019). Historical narratives as strategic resources: analysis of the Turkish international contracting sector. Construction Management and Economics, 37(7), 367-383.

833 Ellis, C. and Bochner, A. (2000). Autoethnography, personal narrative, reflexivity: researcher as subject, in Denzin, Norman and Lincoln, Yvonna (eds.) The Handbook of Qualitative Research, Sage, Thousand Oaks, CA, pp. 733-68.

838 Fairhurst, G. (2007). Discursive Leadership. Thousand Oaks, CA: Sage

840 Fellows, R., Liu, A., and Fong, C. M. (2003). Leadership style and power relations in 841 quantity surveying in Hong Kong. Construction Management and Economics, 21(8), 809842818.

844 Fellows, R. (2010). New research paradigms in the built environment. Construction

845 Innovation, 10(1), 5-13.

847 Flyvbjerg, B. (2006). Five misunderstandings about case-study research. Qualitative Inquiry, 12 (2), pp. 219-245.

850 Fraser, C. (2000). The influence of personal characteristics on effectiveness of construction 851 site managers. Construction management \& economics, 18(1), second decade, 2000-2009. The Leadership Quarterly, 21(6), 922-958. 
857 Gilley, A., McMillan, H. S. and Gilley, J. W. (2009). Organizational change and

858 characteristics of leadership effectiveness. Journal of leadership \& organizational studies,

$85916(1), 38-47$.

860

861 Gill, P.B. (2001). Narrative inquiry: designing the processes, pathways and patterns of

862 change. Systems Research and Behavioral Science: The Official Journal of the International

863 Federation for Systems Research, Vol. 18 No. 4, pp. 335-344.

864

865 Giritli, H. and Oraz, G. T. (2004). Leadership styles: some evidence from the Turkish

866 construction industry. Construction Management and Economics, 22(3), 253-262.

867

868 Guest, G., Bunce, A. and Johnson, L. (2006). How many interviews are enough? An

869 experiment with data saturation and variability. Field methods, 18(1), 59-82.

870

871 Kasapoğlu, E. (2014). Leadership styles in architectural design offices in Turkey. Journal of

872 Construction Engineering and Management, 140(2), 04013047

873

874 Kisfalvi, V. (2002) The Entrepreneur's Character, Life Issues, and Strategy Making - A Field

875 Study, Journal of Business Venturing, 17: 489-518.

876

877 Kotter, J. (1990). A force for change. How leadership differs from management, the Free

878 Press, 1990.

879

880 Langford, DA., Fellows, R., Hancock, M. and Gale, A. Human resource management in

881 construction. London: Longman; 1995.

882

883 Liden, R. C. and Antonakis, J. (2009). Considering context in psychological leadership

884 research. Human relations, 62(11), 1587-1605.

885

886 Lowe, K. B., and Gardner, W. L. (2000). Ten years of the leadership quarterly: Contributions

887 and challenges for the future. The leadership quarterly, 11(4), 459-514. 
889 Löwstedt, M. and Räisänen, C. (2012). 'Playing back-spin balls': narrating organizational 890 change in construction. Construction Management and Economics, Vol. 30 No. 9, pp. 795891806.

893 Löwstedt, M., Räisänen, C. and Leiringer, R. (2018). Doing strategy in project-based 894 organizations: Actors and patterns of action. International journal of project management, $89536(6), 889-898$.

896

897 McCabe, S., Rooke, J., Seymour, D. and Brown, P. (1998) Quality managers, authority and 898 leadership. Construction management and economics, 16(4), 447-457.

899

900 Mhatre, K. H. and Riggio, R. E. (2014). Charismatic and transformational leadership: Past, 901 present, and future. The Oxford handbook of leadership and organizations, 221-240.

902

903 Mäkilouko, M. (2004). Coping with multicultural projects: the leadership styles of Finnish 904 project managers. International Journal of Project Management, 22(5), 387-396.

905

906 Nadler, D. A. and Tushman, M. L. (1994). Beyond the charismatic leader: Leadership and 907 organizational change. The training and development sourcebook, 278-292 $908 \quad 223-233$.

909 Nam, C. H. and Tatum, C. B. (1997). Leaders and champions for construction innovation.

910 Construction management and economics, 15(3), 259-270.

911

912 Northouse, P. (2016). Leadership: Theory and Practice (7th Ed.). Thousand Oaks: Sage. 913

914 Odusami, K. T., Iyagba, R. R. O. and Omirin, M. M. (2003). The relationship between

915 project leadership, team composition and construction project performance in Nigeria.

916 International journal of project management, 21(7), 519-527.

917

918 Ofori, G. (2008). Leadership for future construction industry: Agenda for authentic

919 leadership. International Journal of Project Management, 26(6), 620-630. 
921 Ozorovskaja, R., Voordijk, J. T. and Wilderom, C. P. (2007). Leadership and cultures of

922 Lithuanian and Dutch construction firms. Journal of construction engineering and

923 management, 133(11), 900-911.

924

925 Parker, S. K., and Wu, C. H. (2014). Leading for proactivity: How leaders cultivate staff who

926 make things happen. The Oxford handbook of leadership and organizations, 380-403

927

928 Parry, K W and Bryman, A. (2006). Leadership in organizations. In: S. R. Clegg, C. Hardy,

929 T.B. Lawrence, and W. R. Nord (Eds.), The SAGE handbook of organization studies (2nd

930 ed.). London: Sage.

931

932 Patton, M. (2002). Qualitative research and evaluation methods. 3rd ed. Thousand Oaks,

933 CA:Sage

934

935 Sage, D and Vitry, C. (2018). Introduction: Societies Under Construction, Palgrave

936 Macmillan, Cham, pp. 115-149.

937

938 Seymour, D. and Abd Elhaleem, T. (1991). 'Horses for courses'—effective leadership in

939 construction. International Journal of Project Management, 9(4), 228-232.

940

941 Skipper, C. O. and Bell, L. C. (2006). Assessment with 360 evaluations of leadership

942 behavior in construction project managers. Journal of Management in Engineering, 22(2),

$943 \quad 75-80$.

944

945 Strauss, A. L. and Corbin, J. M. (1990). Basics of qualitative research: Grounded theory

946 procedures and techniques. Thousand Oaks: Sage Publications.

947

948 Sundgren, M. and Styhre, A, (2006). Leadership as de-paradoxification: Leading new drug

949 development work at three pharmaceutical companies, Leadership, 2(1): 31-52.

950

951 Taylor, J.E., Dossick, C.S. and Garvin, M. (2010). Meeting the burden of proof with case-

952 study research. Journal of Construction Engineering and Management, Vol. 137 No. 4, pp.

$953 \quad 303-311$ 
955 Thomas, D. R. (2006). A general inductive approach for analyzing qualitative evaluation

956 data. American journal of evaluation, 27(2), 237-246.

957

958 Toor, S. and Ofori, G. (2007). Leadership research in the construction industry: A review of 959 empirical work and possible future directions. CME 2007 Conference - Construction

960 Management and Economics: 'Past, Present and Future' : 993-1003.

961

962 Tyssen, A. K., Wald, A. and Spieth, P. (2014). The challenge of transactional and

963 transformational leadership in projects. International Journal of Project Management, 32(3),

$964 \quad 365-375$.

965

966 Yin, R.K. (2013).Validity and generalization in future case study evaluations. Evaluation, 967 19(3), pp. 321-332.

968

969 Yuk1, G (2008) "Leadership in organizations". New Jersey: Prentice Hall. Upper Saddle 970 River.

971

972 Wang, G., Oh, I. S., Courtright, S. H. and Colbert, A. E. (2011). Transformational leadership 973 and performance across criteria and levels: A meta-analytic review of 25 years of research.

974 Group \& organization management, 36(2), 223-270.

975

976 Wong, J., Wong, P. N. and Heng, L. (2007). An investigation of leadership styles and 977 relationship cultures of Chinese and expatriate managers in multinational construction 978 companies in Hong Kong. Construction Management and Economics, 25(1), 95-106. 979

$980 \quad$ TABLES 1 and 2

981 Table 1. Overview of the overarching themes used in the interviews. 
We asked the managers to tell us their professional stories, starting with their educational backgrounds, followed by a description of their career trajectories leading up to their current positions. We also asked them what professional requirements (competencies and experience) had qualified them for their current managerial position.

\section{Leadership definition and orientation}

We asked for their definitions of leadership and then for a detailed description of their own leadership philosophies, styles, and practices

\section{Leadership practice}

This perspective informed our follow-up questions throughout all the interviews. Rather than only letting them talk about leadership in abstract and general terms, we constantly asked them to provide concrete and detailed examples from day-to-day organizational life, linking leadership to the actual conditions of their work.

\section{Leadership differences}

We asked how leadership is different in the construction industry compared to other industries and contexts. While almost none of the managers had any actual experience from working in any other industry, their reflections on the perceived differences offered a rich stock of accounts that elucidated the specifics of construction in terms of a leadership context.

\section{Leadership in change}

We asked if and how the leadership styles had changed from past to present time. We also asked them to speculate about the future, specifically to reflect on the role that leadership 
might have for the wide range of challenges faced by construction companies and their managers.

982

983 Table 2. A detailed overview of the analytical process. 
Selective code:

Leadership vis-á-vis

Axial codes:

other skills

Informal and formal work

Open codes:

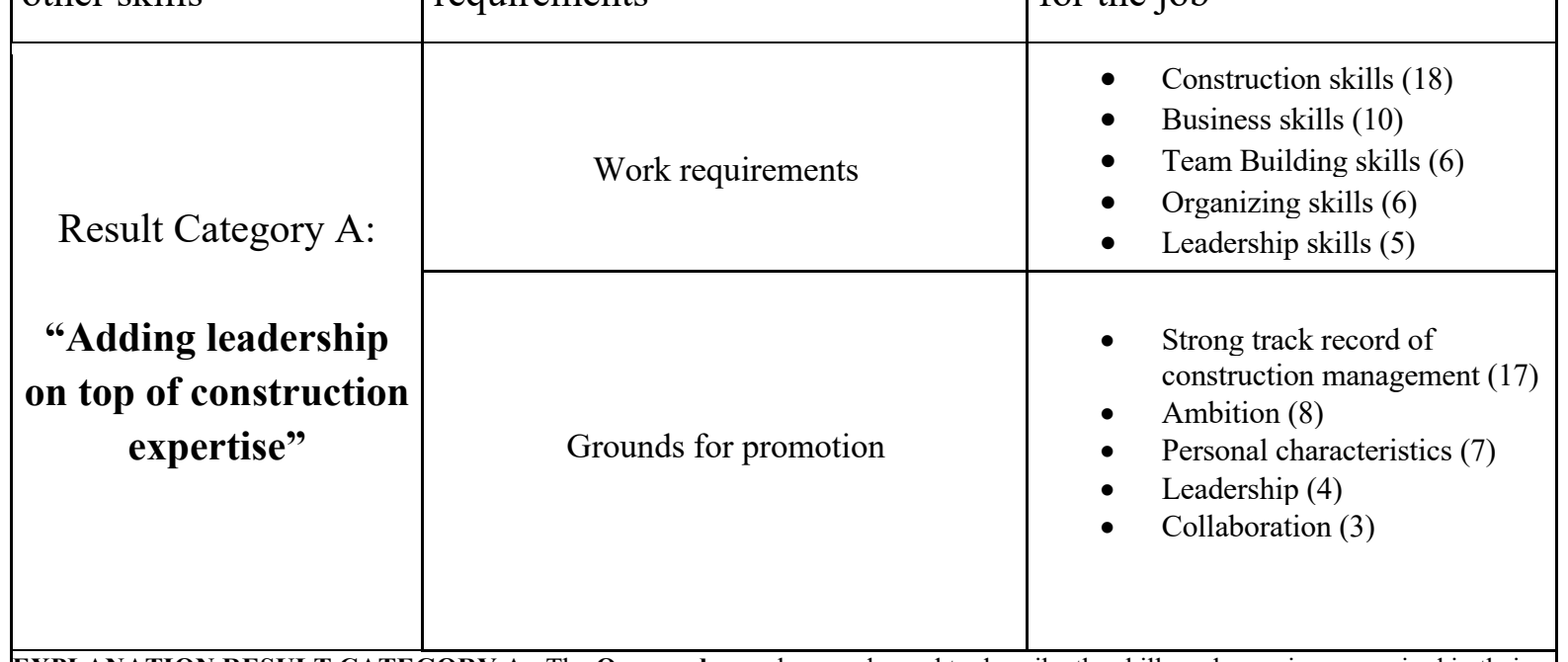

EXPLANATION RESULT CATEGORY A: The Open codes are keywords used to describe the skills and experience required in their jobs (numbers in brackets indicate the number of interviewees that included them as part of their descriptions). Only keywords mentioned in more than one interview are included here. The Axial codes distinguish between how they described the work requirements in general and how they answered the direct question: "on what basis did you get promoted to your current position?". While there exist many possible overlaps across the Open codes listed here, the aggregated Selective Code represents the strong preference and priority given to construction expertise, experience, and track record, in which other skills, including leadership, are given secondary importance. This analytical inference is further supported by the fact that an aggregated summary of the managers' professional backgrounds shows that 20/24 of the managers have worked their whole careers in construction companies, and only $4 / 24$ have been recruited from other organizational contexts. Number 1 of these exceptions was recruited from a real estate company. Number 2 started the career in construction and switched over to the transport sector for a brief period of time, but then missed working in construction and therefore returned back. Number 3 worked in academia as a researcher and was recruited to the central functions working with organizational development. Number 4 had a profile that stood out, by having experience from working as a manager in a large multinational car company.

\begin{tabular}{|c|c|c|}
\hline $\begin{array}{l}\text { Selective code: } \\
\text { Overall Leadership } \\
\text { Approach }\end{array}$ & $\begin{array}{l}\text { Axial codes: } \\
\text { Leadership themes }\end{array}$ & $\begin{array}{l}\text { Open codes: } \\
\text { Keyword used to describe } \\
\text { leadership }\end{array}$ \\
\hline \multirow{4}{*}{$\begin{array}{l}\text { Result Category B: } \\
\text { "Responsive } \\
\text { Leadership" }\end{array}$} & Listen (rather than telling) & $\begin{array}{ll}\text { - } & \text { Listen (19) } \\
\text { - } & \text { Trying to understand the needs } \\
\text { of others (15) } \\
\text { - } \quad \text { Facilitate open dialogues (9) } \\
\text { - } \quad \text { "See" others (8) } \\
\text { - } \quad \text { Negotiate consensus (8) } \\
\text { - } & \text { Coaching (6) }\end{array}$ \\
\hline & Being personal and flexible & $\begin{array}{ll}\text { - } & \text { Adapt/adjust leadership to } \\
\text { different personalities (15) } \\
\text { - } & \text { Be skilled in the 'people } \\
\text { business' (15) } \\
\text { - } \\
\text { Be friendly and informal (14) }\end{array}$ \\
\hline & Accommodate needs & $\begin{array}{l}\text { - Trying to accommodate the } \\
\text { work-related needs of others } \\
\text { (17) } \\
\text { - Trying to accommodate the } \\
\text { personal development of } \\
\text { others (14) }\end{array}$ \\
\hline & Responsiveness (11) & $\begin{array}{l}\text { The English translation of the Swedish } \\
\text { word "Lyhördhet", the meaning of } \\
\text { which encapsulates a combination of the } \\
\text { three previous axial codes: listen and } \\
\text { understand the needs of the employees, } \\
\text { with the purpose of trying to } \\
\text { accommodate those needs by being } \\
\text { flexible }\end{array}$ \\
\hline
\end{tabular}

EXPLANATION RESULT CATEGORY B: The three columns here represent a three-step aggregation of the managers' leadership descriptions (only descriptions used in more than one interview is included here). "Responsiveness" is listed both as the overall Selective code and one of the four Axial codes. This is because it was used both directly as a leadership keyword as well as representing a central notion in the descriptions of leadership styles, that permeates all the Axial codes. 11/24 of the managers used "Responsiveness" directly 


\begin{tabular}{|c|c|c|}
\hline $\begin{array}{l}\text { Selective Code: } \\
\text { Responsive Leadership } \\
\text { as an organizing } \\
\text { principle }\end{array}$ & $\begin{array}{l}\text { Axial codes: } \\
\text { Logical linkages between } \\
\text { Responsive Leadership and daily } \\
\text { managerial work tasks and } \\
\text { organizing challenges }\end{array}$ & Open codes: \\
\hline \multirow{4}{*}{$\begin{array}{l}\text { Result Category C: } \\
\text { "The alignment } \\
\text { between leadership } \\
\text { and current } \\
\text { organizing } \\
\text { principles" }\end{array}$} & $\begin{array}{l}\text { Delegating "freedom with responsibility" } \\
\text { (evaluating work outcomes rather than } \\
\text { work methods) }\end{array}$ & \multirow{4}{*}{ Same as Category B } \\
\hline & $\begin{array}{l}\text { Allowing high degrees of flexibility for } \\
\text { work tasks is a requirement for the } \\
\text { complex problem-solving needed }\end{array}$ & \\
\hline & $\begin{array}{l}\text { To listen (rather than telling) was } \\
\text { perceived as the most effective way to } \\
\text { empower employees, which in turn } \\
\text { supports task performance }\end{array}$ & \\
\hline & $\begin{array}{l}\text { Marked a clear contrast to more directing } \\
\text { and coercive leadership styles that were } \\
\text { deemed inappropriate in general } \\
\text { (key metaphors: "NOT being a dictator", } \\
\text { "NOT being a micromanager", "NOT } \\
\text { pointing with the whole hand") }\end{array}$ & \\
\hline \multicolumn{3}{|c|}{$\begin{array}{l}\text { EXPLANATION RESULT CATEGORY C: Category C prolongs Category B to link "Responsive Leadership" to the corresponding } \\
\text { organizing principles. This analytical step thus reviewed all the concrete examples and explanations of "Responsive Leadership" as it was } \\
\text { used to support the situated managerial work tasks and organizing challenges in the construction companies studied. }\end{array}$} \\
\hline $\begin{array}{c}\text { Selective code: } \\
\text { Comparing axial codes } \\
\text { with Result Categories } \\
\text { B and C }\end{array}$ & $\begin{array}{l}\text { Axial codes: } \\
\text { Organizing principles }\end{array}$ & $\begin{array}{l}\text { Open codes: } \\
\text { Organizational challenges } \\
\text { (ongoing and future) }\end{array}$ \\
\hline \multirow{4}{*}{$\begin{array}{l}\text { Result Category D: } \\
\text { "The tension between } \\
\text { leadership and future } \\
\text { organizing principles " }\end{array}$} & Standardization & \multirow{4}{*}{ 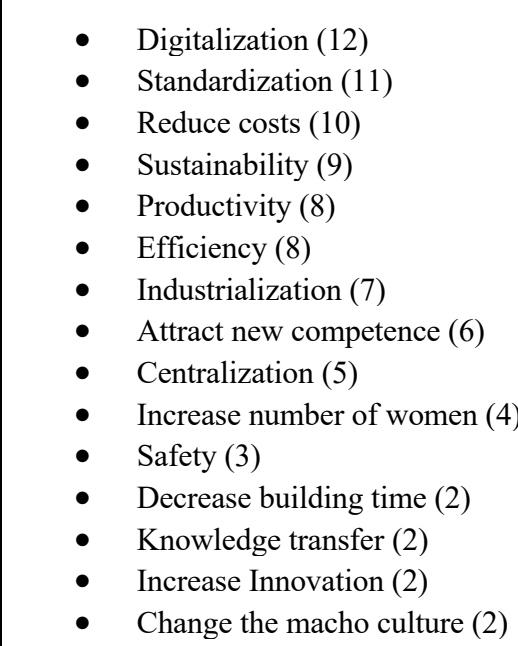 } \\
\hline & Centralization & \\
\hline & Integrated multi-level processes & \\
\hline & $\begin{array}{l}\text { Top-down directions } \\
\text { (Mandatory, rather than guiding) }\end{array}$ & \\
\hline
\end{tabular}


EXPLANATION RESULT CATEGORY D: The Open codes list all the organizational challenges (ongoing and future) mentioned by the interviewees (including only those mentioned in more than one interview). The Axial code column represents the most accentuated organizing logics that were linked to these challenges. The Selective code represents the overall tension found by comparing the converging logic throughout the Axial Codes with the Result Categories B and C. In the result and discussion sections we draw also on the fact that most of the organizational challenges outlined here are directly or indirectly related to an overall strive to improve the performance of construction processes and organizing (regarding a variety of different performance dimensions, such as time, cost, quality, productivity, efficiency, waste elimination).

984 